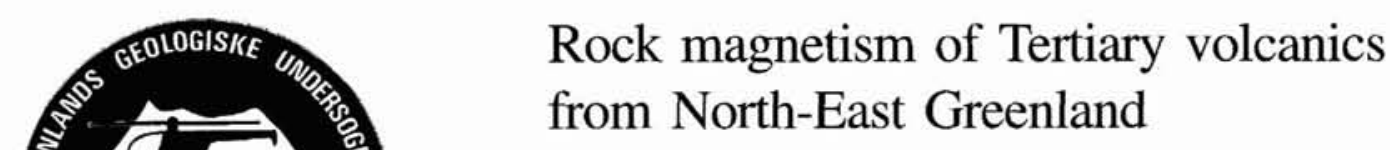

\author{
Niels Abrahamsen \& Petur Nordgerd
}

\begin{abstract}
Rock magnetic results from 8 profiles covering stratigraphically the northern part of the Early Tertiary volcanic province in North-East Greenland $\left(73^{\circ} 30^{\prime}-75^{\circ} \mathrm{N}\right)$ are summarised. Tests in the field revealed only reversed polarities, which are likely to fall in the time span between chron $24 \mathrm{r}$ and $26 \mathrm{r}$. Mean magnetic susceptibilities from 60 sites (some 2100 in situ measurements), together with average values of the intensity of the NRM (based upon 160 samples from 37 flows and dykes) and corresponding $Q$ ratios, are tabulated. The overall means and standard deviations are $k=0.010 \mathrm{SI}$ (s.d. = $0.003), J=1.7 \mathrm{~A} / \mathrm{m}$ (s.d. = 1.3) and $Q=2.8$ (s.d. = 3), respectively. The susceptibilities are normally distributed, in contrast to the NRM intensity values and the $Q$ ratios, which tend to be log-normal distributed.
\end{abstract}

N. A. \& P. N., Department of Earth Sciences, Aarhus University, 8000 Aarhus C, Denmark.

Magnetic investigations on the Tertiary basalts of North-East Greenland were made (1) to provide geophysical background information of the magnetic properties for aeromagnetic interpretations; and (2) to search for and identify stratigraphical polarity zones, which might be useful for regional correlation and dating by means of the marine magnetic anomaly scale.

The combined profiles investigated magnetically cover the greater part of the Early Tertiary volcanic sequence in North-East Greenland $\left(73^{\circ} 30^{\prime}-75^{\circ} \mathrm{N}\right)$; the most extensive areas of Tertiary basalts are exposed further south in the Scoresby Sund region of central East Greenland (Deer, 1976; Larsen et al., 1989). The northern volcanic area, the total thickness of which is of the order of $1 \mathrm{~km}$ (Noe-Nygaard, 1976; Upton et al., 1980), is shown on the index-map (Fig. 1), on which the individual profiles are located. A geological review, together with a more detailed description of the geology and suggested correlation between the profiles investigated, is given by Watt (1994).

In 1989 (Nordgerd, 1991) about 2100 in situ measurements of the magnetic susceptibility $(k)$ were made with a kappameter (Model KT-5, Geofyzika Brno), and the polarity was estimated in the field by means of a portable fluxgate magnetometer (Model BR-2, FG Electronics). A collection of orientated samples was obtained for more detailed palaeomagnetic studies in the laboratory, the results of which will be reported elsewhere.

\section{Magnetic polarity}

Only reversely magnetised flows and dykes were encountered in the 8 partly overlapping profiles discussed here (Fig. 1, Table 1). In the Early Tertiary plateau basalts of the Scoresby Sund region the basalt succession investigated showed only reversed polarity (Tarling $\mathrm{et}$ al., 1988); the few normal polarities known from field measurements did not stand magnetic cleaning in the laboratory. The only normal polarity reported from the Tertiary volcanics in the northern area are field test results from the upper part of the Upper Plateau Lava Series at Hold with Hope (Upton et al., 1980, p. 497) which have not been tested by magnetic cleaning experiments in the laboratory; hence it may be due to secondary induced younger magnetic overprints.

On the basis of the measured polarities it may be concluded, that the Lower Plateau Lava Series and the lowest part of the Upper Plateau Lava Series of the northern volcanic area are dominated by reversely magnetised lava flows (shorter intervals of normal polarity could be missing in the sequence due to volcanically quiet time intervals or hiati separating consecutive flows); a part of the Upper Plateau Lava Series may be of normal polarity. Tertiary sills of somewhat uncertain age intruded into Mesozoic sediments below the flows show both reverse and normal polarities (Upton et al., 1980), whereas a younger NE-SW trending dyke swarm shows normal polarity (Upton et al., 1980).

The age of the extensive reversed polarity of the Lower Plateau Lava Series may fall within the c. 2.5 Ma long polarity chron $24 \mathrm{r}$ (c. 54.7-57.2 Ma; Harland et al., 
Table 1. Site mean values and statistics of susceptibility, NRM and $Q$ ratio

\begin{tabular}{|c|c|c|c|c|c|c|c|c|c|c|c|}
\hline \multirow[b]{2}{*}{ No } & \multirow[b]{2}{*}{ Locality } & \multirow[b]{2}{*}{ Flow } & \multirow[b]{2}{*}{ Alt. $\mathrm{m}$} & \multirow[b]{2}{*}{$n$} & \multicolumn{2}{|c|}{$\begin{array}{l}\text { Susceptibility } \\
\text { Log-mean St.dev. }\end{array}$} & \multirow[b]{2}{*}{ Mean } & \multirow[b]{2}{*}{ St.dev. } & \multicolumn{2}{|c|}{ NRM } & \\
\hline & & & & & $\begin{array}{c}\text { Log-mean } \\
10^{3} \mathrm{SI}\end{array}$ & $\begin{array}{l}\text { Log. } \\
\text { tov. }\end{array}$ & & & $n$ & $\mathrm{~A} / \mathrm{m}$ & $\mathrm{NRM} / k F$ \\
\hline 1 & Gransedalen & 1 & 500 & 35 & 9.5 & 1.7 & 9.6 & 1.7 & 5 & 1.70 & 4.5 \\
\hline 2 & & 2 & 532 & 32 & 6.7 & 1.3 & 6.9 & 1.2 & & & \\
\hline 3 & & 3 & 560 & 35 & 7.3 & 0.8 & 7.4 & 1.0 & 5 & 0.72 & 2.5 \\
\hline 4 & & 5 & 600 & 12 & 14.3 & 3.0 & 14.6 & 3.0 & & & \\
\hline 5 & & 8 & 675 & 12 & 12.8 & 2.7 & 13.1 & 2.8 & & & \\
\hline 6 & & 11 & 710 & 36 & 12.7 & 2.0 & 12.9 & 2.1 & 5 & 5.25 & 10.4 \\
\hline 7 & & 12 & 722 & 36 & 13.7 & 1.8 & 13.8 & 1.7 & 5 & 2.80 & 5.1 \\
\hline 8 & & 16 & 766 & 35 & 12.6 & 1.6 & 12.7 & 1.5 & 5 & 0.33 & 0.7 \\
\hline 9 & & 17 & 816 & 35 & 9.3 & 1.5 & 9.4 & 1.4 & 5 & 1.42 & 3.8 \\
\hline 10 & & 19 & 835 & 35 & 10.7 & 3.3 & 11.3 & 3.7 & 5 & 4.92 & 11.6 \\
\hline 11 & & 25 & 910 & 35 & 8.7 & 2.2 & 8.9 & 1.7 & 5 & 1.25 & 3.6 \\
\hline 12 & & 27 & 950 & 36 & 9.5 & 2.4 & 9.7 & 2.1 & & 5.08 & 13.4 \\
\hline 13 & & 28 & 1020 & 12 & 11.4 & 1.4 & 11.5 & 1.4 & & 1.26 & 2.8 \\
\hline 14 & & 30 & 1035 & 39 & 12.5 & 2.8 & 12.8 & 2.9 & & 0.47 & 0.9 \\
\hline 15 & & 31 & 1070 & 39 & 11.6 & 3.9 & 12.2 & 4.1 & & & \\
\hline 16 & Shannon Kap David Gray & sill & & 13 & 15.2 & 2.2 & 15.4 & 2.3 & 4 & 1.10 & 1.8 \\
\hline 17 & castern & sill & & 38 & 1.8 & 1.2 & 2.3 & 2.2 & 4 & 0.30 & 4.2 \\
\hline 18 & Kap Pansch & 1 & 110 & 35 & 3.4 & 1.9 & 3.9 & 2.5 & 3 & 0.46 & 3.4 \\
\hline 19 & Little Pendulum & 1 & 284 & 37 & 14.0 & 2.4 & 14.2 & 2.3 & 5 & 1.03 & 1.8 \\
\hline 20 & & 5 & 351 & 13 & 13.2 & 2.0 & 13.3 & 1.9 & 5 & 1.25 & 2.4 \\
\hline 21 & & 6 & 376 & 38 & 19.9 & 2.0 & 20.0 & 1.9 & 5 & 1.63 & 2.1 \\
\hline 22 & & 9 & 432 & 38 & 11.2 & 1.8 & 11.4 & 1.9 & 5 & 0.58 & 1.3 \\
\hline 23 & & 11 & 445 & 37 & 11.8 & 2.6 & 12.1 & 2.6 & 5 & 0.53 & 1.1 \\
\hline 24 & & 13 & 472 & 38 & 9.5 & 1.3 & 9.6 & 1.3 & 5 & 3.59 & 9.5 \\
\hline 25 & & 14 & 480 & 37 & 14.9 & 1.6 & 15.0 & 1.6 & 5 & 3.23 & 5.4 \\
\hline 26 & & 15 & 485 & 37 & 5.8 & 0.7 & 5.9 & 0.8 & 5 & 0.82 & 3.6 \\
\hline 27 & & 16 & 505 & 37 & 10.0 & 1.8 & 10.2 & 1.8 & 5 & 1.74 & 4.4 \\
\hline 28 & & dyke & 580 & 39 & 3.1 & 1.1 & 3.4 & 1.4 & & & \\
\hline 29 & & dyke & & 39 & 14.3 & 2.6 & 14.5 & 2.5 & & & \\
\hline 30 & Sabine $\emptyset$, Germania Bjerg & 4 & 225 & 37 & 7.8 & 2.0 & 8.0 & 2.0 & 5 & 1.33 & 4.3 \\
\hline 31 & & 5 & 252 & 38 & 8.5 & 1.9 & 8.7 & 1.6 & 5 & 1.18 & 3.5 \\
\hline 32 & Nålene & 1 & 630 & 36 & 8.8 & 4.4 & 9.4 & 2.1 & 5 & 2.15 & 6.1 \\
\hline 33 & & dyke & 680 & 38 & 9.0 & 2.9 & 9.4 & 2.8 & 2 & 1.97 & 5.5 \\
\hline 34 & & 3 & 720 & 37 & 8.3 & 1.4 & 8.5 & 1.4 & 5 & 2.61 & 7.9 \\
\hline 35 & & 5 & 740 & 38 & 5.9 & 1.1 & 6.0 & 1.1 & 5 & 0.68 & 2.9 \\
\hline 36 & & 8 & 790 & 38 & 7.9 & 1.9 & 8.2 & 2.4 & 5 & 1.71 & 5.4 \\
\hline 37 & & 15 & 885 & 38 & 12.5 & 1.9 & 12.6 & 1.9 & 5 & 0.78 & 1.6 \\
\hline 38 & & 19 & 965 & 39 & 11.6 & 3.3 & 12.0 & 2.8 & 5 & 1.65 & 3.6 \\
\hline 39 & & 21 & 1003 & 38 & 5.8 & 4.1 & 7.4 & 5.8 & 5 & 3.27 & 14.2 \\
\hline 40 & & 27 & 1115 & 39 & 13.3 & 4.8 & 14.2 & 5.4 & 5 & 0.71 & 1.3 \\
\hline 41 & Dr. Augustadalen & dykel & 500 & 77 & 8.4 & 1.7 & 8.5 & 1.6 & 2 & 1.97 & 5.9 \\
\hline 42 & & $\mathrm{dk} 2$, marg & & 52 & 6.4 & 2.0 & 6.7 & 1.9 & & & \\
\hline 43 & & $\mathrm{dk} 2$, centr & & 26 & 11.6 & 1.3 & 11.6 & 1.2 & & & \\
\hline 44 & Palnatoke Bjerg & 1 & 715 & 38 & 6.0 & 0.6 & 6.0 & 0.7 & & & \\
\hline 45 & & 2 & 725 & 37 & 8.8 & 1.3 & 8.8 & 1.2 & & & \\
\hline 46 & & 3 & 772 & 37 & 6.8 & 2.6 & 7.1 & 1.3 & & & \\
\hline 47 & & 5 & 810 & 12 & 4.9 & 0.2 & 4.9 & 0.2 & & & \\
\hline 48 & & 12 & 1030 & 35 & 9.6 & 1.3 & 9.7 & 1.2 & & & \\
\hline 49 & & 13 & 1038 & 36 & 7.4 & 0.9 & 7.5 & 0.9 & & & \\
\hline 50 & & 14 & 1045 & 37 & 10.4 & 1.7 & 10.5 & 1.6 & & & \\
\hline 51 & & 15 & 1064 & 39 & 9.5 & 2.2 & 9.7 & 2.5 & & & \\
\hline 52 & Haredal & 2 & 520 & 39 & 9.5 & 3.1 & 10.0 & 2.8 & & & \\
\hline 53 & & 3 & 550 & 36 & 9.3 & 1.0 & 9.4 & 1.1 & & & \\
\hline 54 & & 4 & 587 & 39 & 11.1 & 1.8 & 11.2 & 1.7 & & & \\
\hline 55 & & 5 & 600 & 37 & 11.9 & 1.9 & 12.1 & 1.9 & & & \\
\hline 56 & & 8 & 620 & 37 & 12.2 & 2.4 & 12.4 & 2.4 & & & \\
\hline 57 & & 9 & 632 & 38 & 9.8 & 1.2 & 9.9 & 1.1 & & & \\
\hline 58 & & 10 & 655 & 38 & 16.0 & 4.9 & 16.8 & 5.8 & & & \\
\hline 59 & Kuhn $\emptyset$. Schwarze Wand & 1 & 1056 & 39 & 12.3 & 1.6 & 12.4 & 1.4 & 5 & 1.85 & 3.8 \\
\hline 60 & & 6 & 1140 & 34 & 11.4 & 2.4 & 11.7 & 2.3 & 5 & 1.19 & 2.6 \\
\hline & & - & & - & - & & - & & - & - & - \\
\hline & Total & 60 & & 2119 & & & & & 160 & & \\
\hline & Average & & & & 10.07 & & 10.32 & & & 74 & 2.82 \\
\hline & St. dev. & & & & 3.3 & & 3.3 & & & & 3.4 \\
\hline & Average (log) & & & & 9.39 & & 9.69 & & & 35 & \\
\hline & St. dev. (log) & & & & 1.0 & & 1.0 & & & & \\
\hline
\end{tabular}




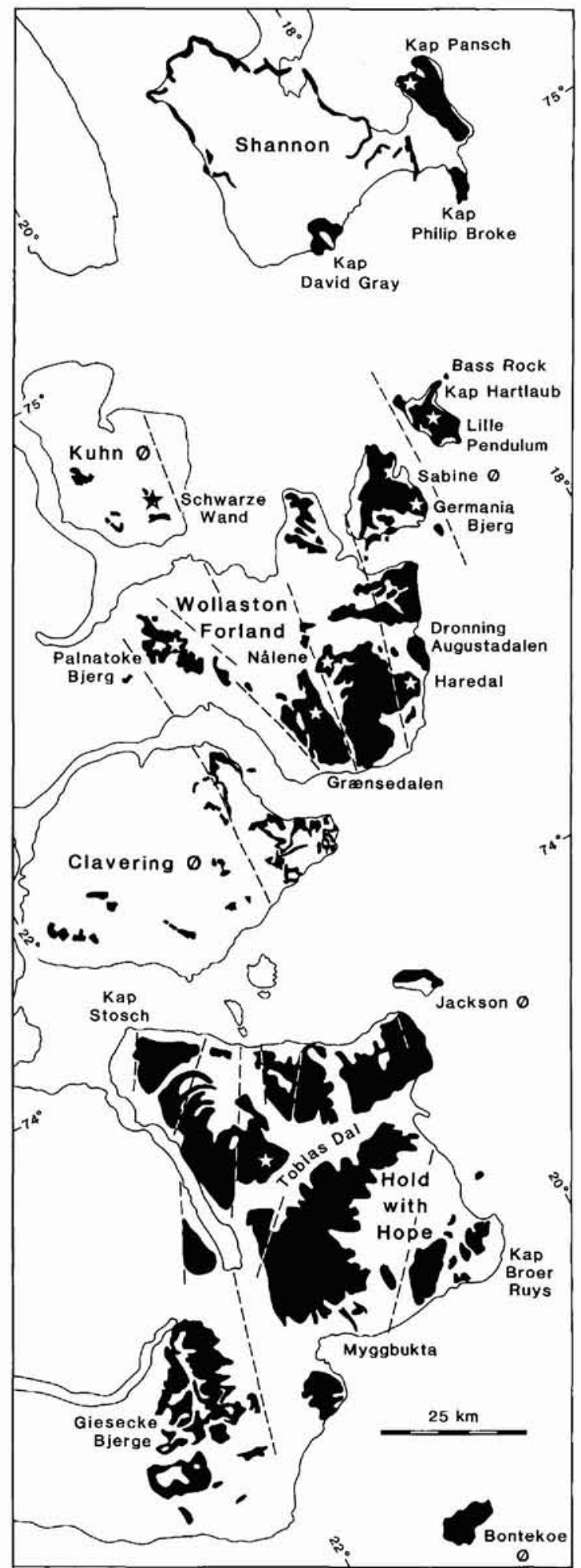

Fig. 1. Geological overview map showing the areas (black) with early Tertiary volcanics in North-East Greenland between $73.5^{\circ}$ and $75^{\circ} \mathrm{N}$ (modified from Watt, 1994). Profiles and sampling sites listed in Table 1 are also indicated.

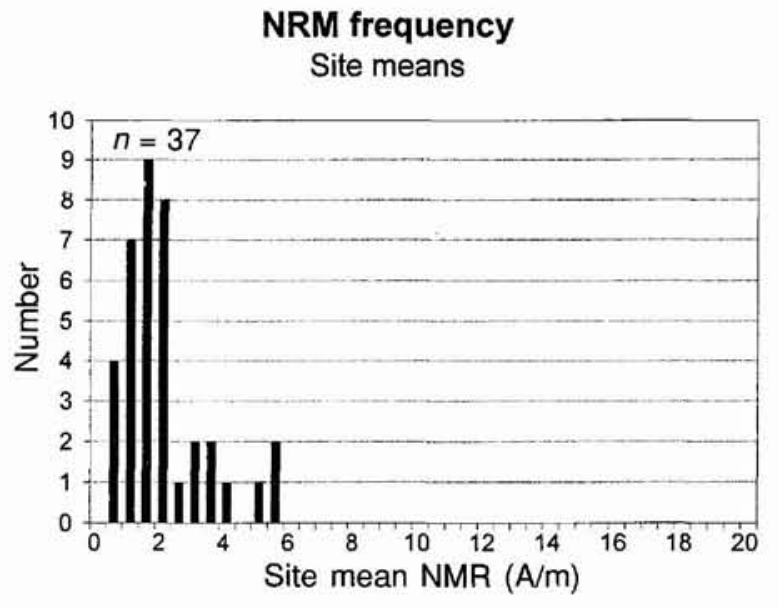

Fig. 2. Frequency distribution of the NRM intensity (site means).

1990). However, the earlier reversed, but shorter, Chrons $25 \mathrm{r}$ and $26 \mathrm{r}$ cannot be entirely ruled out. In other related areas, several reversals are known from the Early Tertiary volcanic sequences in West Greenland (e.g. Tarling \& Otulana, 1972; Kristiansson \& Deutsch, 1973; Sharma, 1976; P. Riisager \& N. Abrahamsen, unpublished) as well as in the approximately contemporary flows making up the $3 \mathrm{~km}$ lava pile of the Faeroe Islands (e.g. Tarling, 1970; Abrahamsen et al., 1984; Waagstein, 1988).

\section{Intensity of the NRM}

The intensity of the NRM (Natural Remanent Magnetisation) is summarised in Table 1, and the site positions are shown in Figure 1. The site mean NRM (Fig. 1) for samples from 37 sites measured in the laboratory varies between 0.3 and $5.2 \mathrm{~A} / \mathrm{m}$, with an average of $1.7 \mathrm{~A} / \mathrm{m}$ (s.d. 1.3). The arithmetical and geometrical means do not

\section{$Q$ ratio frequency Site means}

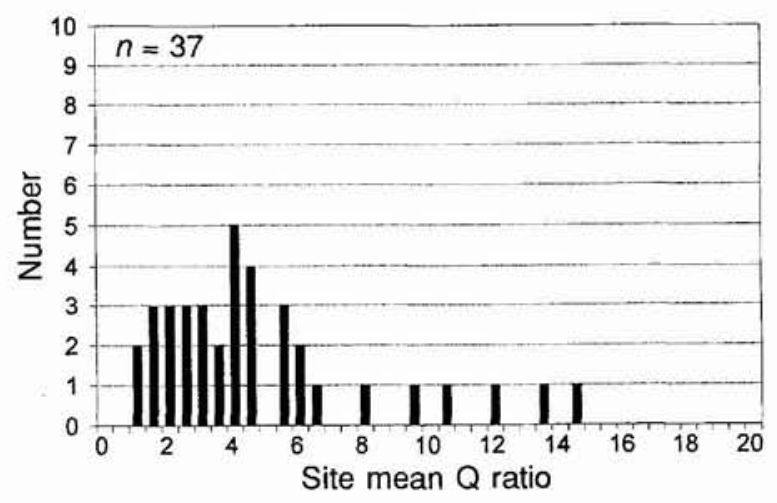

Fig. 3. Frequency distribution of the $Q$ ratio (site means). 


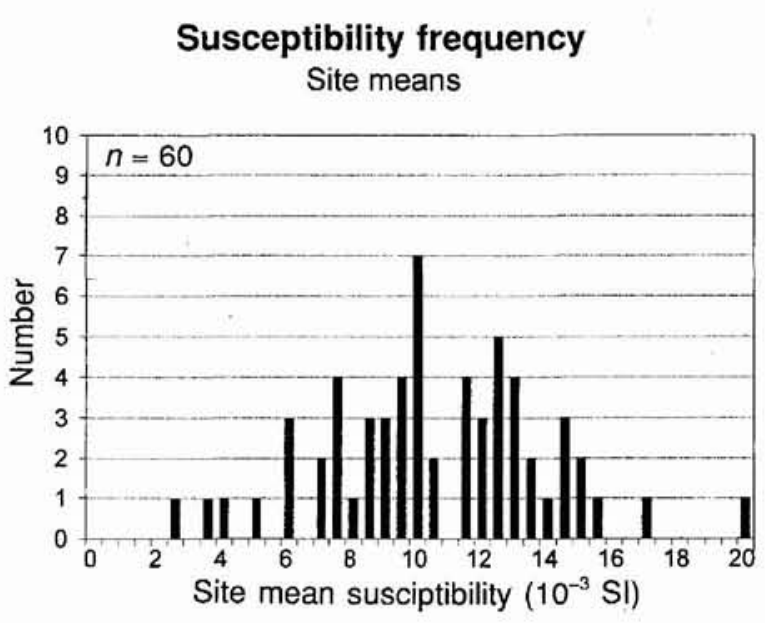

Fig. 4. Frequency distribution of the susceptibility (site means).

differ significantly from each other (1.74 and 1.35 , respectively), although the frequency distribution is skewed to the right, as illustrated in Figure 2.

\section{$Q$ ratio}

When making magnetic modelling calculations, it may be important to know the relative importance of the NRM intensity as compared to the induced magnetisation. This ratio is described by the so-called $Q$ ratio, $Q=J_{\mathrm{NRM}} /(k F)$. In this ratio the $J_{\mathrm{NRM}}$ is the intensity of the NRM, $k$ is the susceptibility, and $F(=0.5 \mathrm{Oe})$ is the intensity of the inducing ambient earth magnetic field. As the site mean NRM intensity has a log-normal distribution (Fig. 2) and the susceptibility in this case (see below) is a normal distribution (Fig. 4), then the site mean $Q$ ratio must also have a log-normal distribution, as is seen in Figure 3.

\section{Susceptibility}

The in situ site mean susceptibility for 60 sites (2119 measurements) varies between 2 and $20 \times 10^{-3} \mathrm{SI}$, with an average of around $10 \times 10^{-3} \mathrm{SI}$ (Table 1). The frequency distribution for the site means is shown in Figure 4 , and the frequency distribution of all measurements is shown in Figure 5. In both cases the distribution is fairly close to a normal distribution by visual inspection. This is not typical for volcanic rocks, as the two rock magnetic parameters susceptibility and NRM intensity are usually expected to be better represented by a log-normal distribution (e.g. Tarling, 1966; Abrahamsen \& Van der Voo, 1987; Henkel, 1991). In Table 1, site mean values and standard errors are calculated for a log-normal as well as a normal distribution. Differences between the two types of statistics for these volcanics are minor. For the overall means the difference is only $3 \%$.

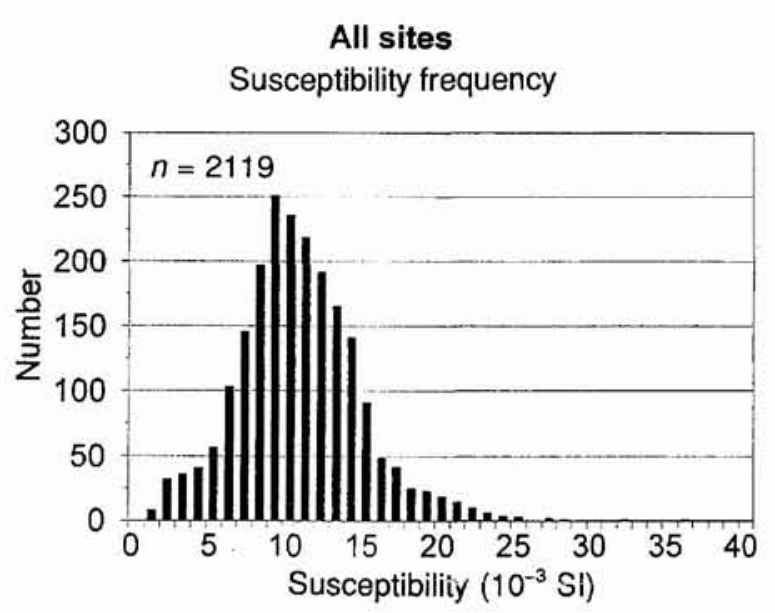

Fig. 5. Frequency distribution of the susceptibility (all sites).

In contrast to the overall distribution, individual profiles with a smaller number of measurements may show distributions which are more irregular. In Figure 6 (a-g), susceptibility frequencies for 7 profiles or groups are illustrated. The profile of Little Pendulum has a fairly symmetrical distribution, whereas the other profiles are less symmetrical; Kuhn $\varnothing$ is skewed to the left, the other five profiles are skewed to the right. The mean values for each site and profile are summarised in Table 1.

\section{Conclusions}

The rock magnetic results for most of the northern part of the Lower and Upper Plateau Lava Series of the Early Tertiary volcanic province in North-East Greenland $\left(73^{\circ} 30^{\prime}-75^{\circ} \mathrm{N}\right)$ are summarised. Mean magnetic susceptibilities from 60 sites (based upon some 2100 in situ measurements), together with average values of the in-

\section{Grænsedalen (15 sites)}

Susceptibility frequency

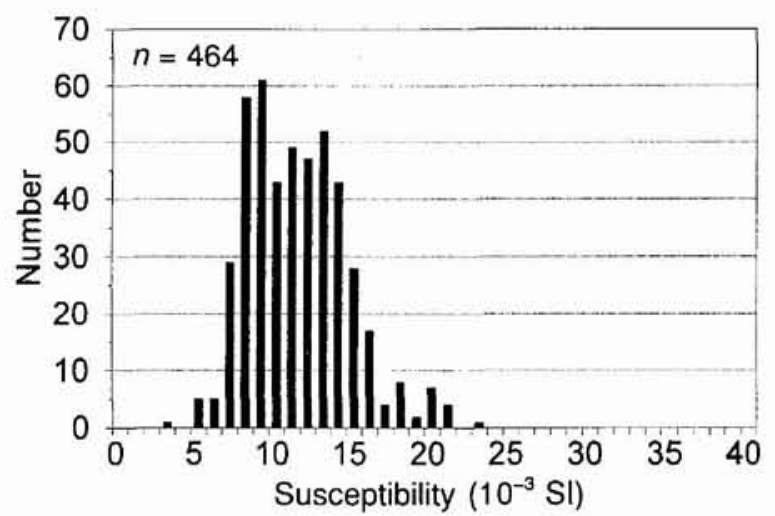

Fig. 6. Susceptibility histograms of individual localities. 
Shannon (3 sites)

Susceptibility frequency

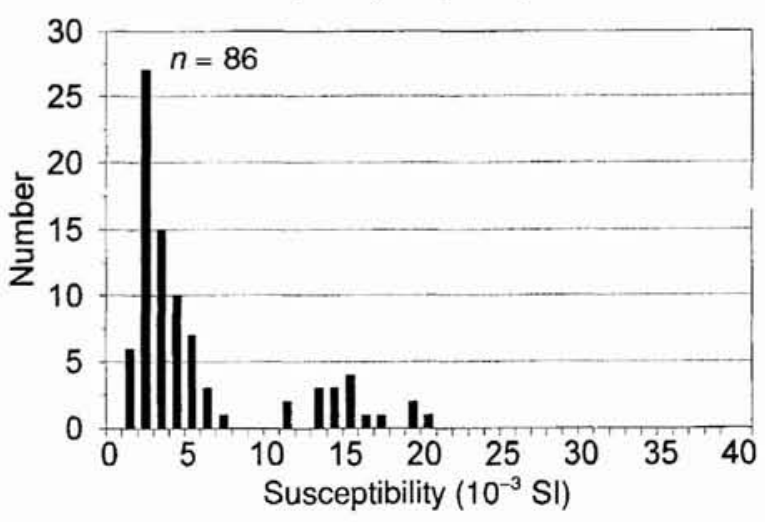

\section{Little Pendulum (11 sites)}

Susceptibility frequency

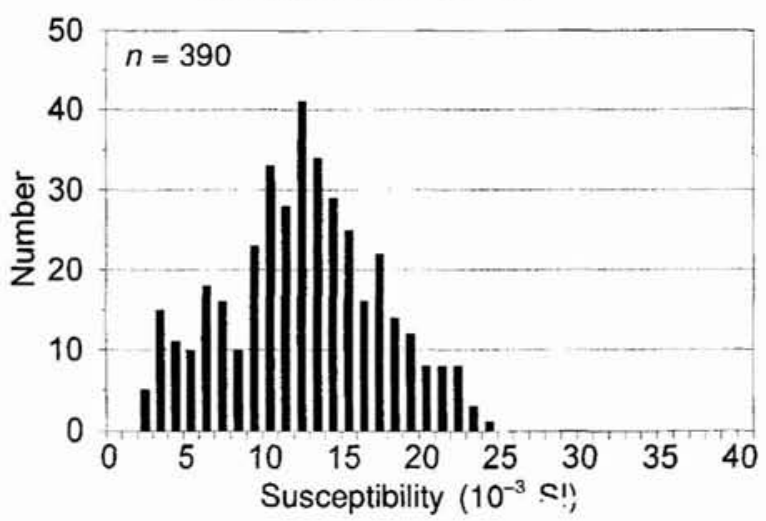

Nálene (12 sites)

Susceptibility frequency

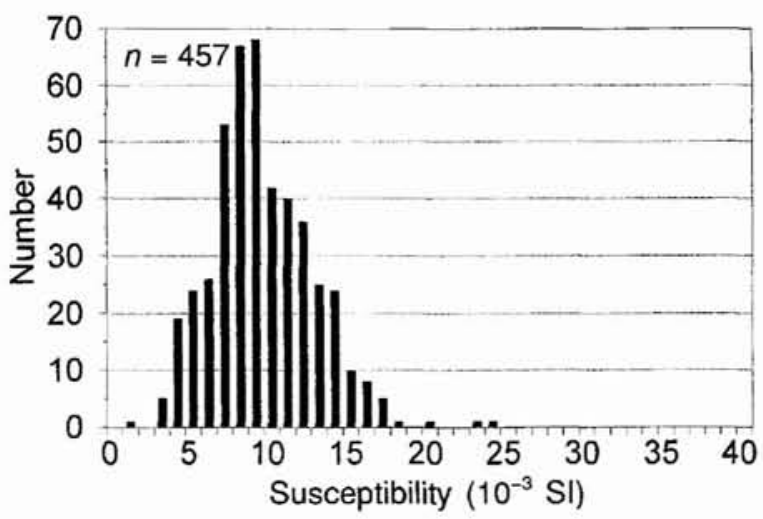

Haredal (7 sites)

Susceptibility frequency

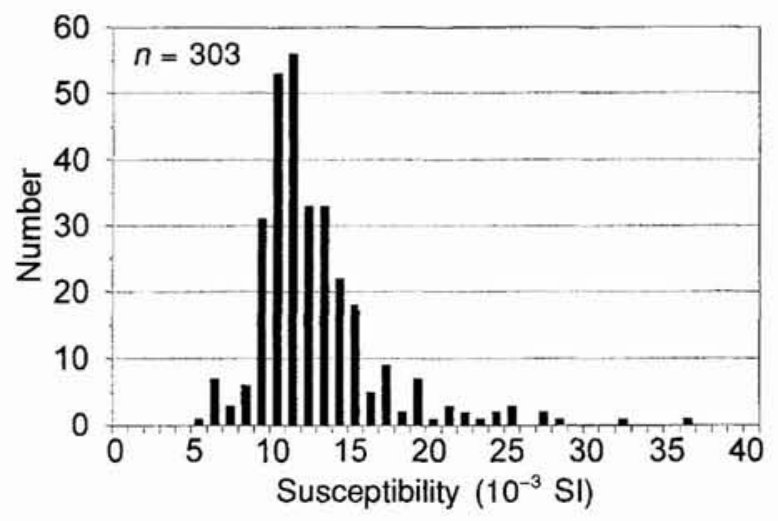

Palnatoke Bjerg (8 sites)

Susceptibility frequency

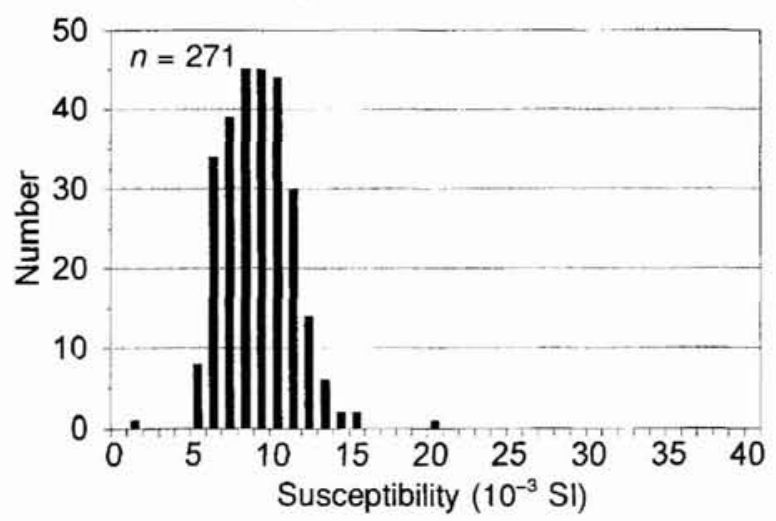

Kuhn Ø (2 sites)

Susceptibility frequency

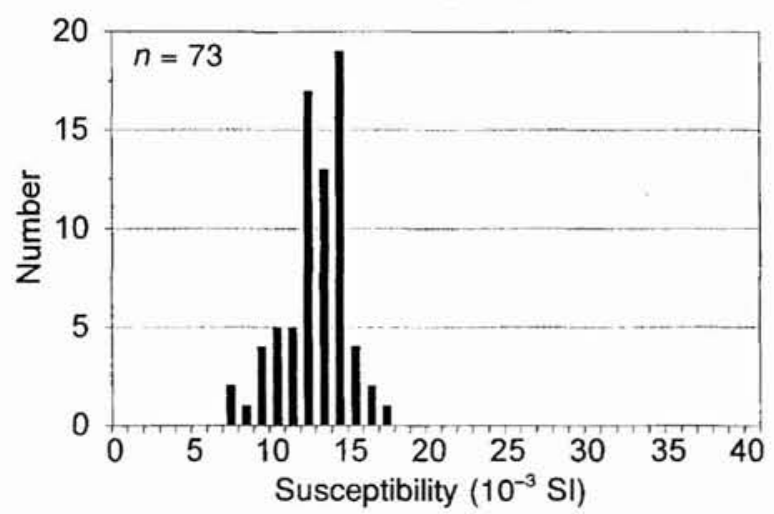

Fig. 6. Cont. 
tensity of the NRM (based upon 160 samples from 37 flows and dykes) and corresponding $Q$ ratios, are tabulated and illustrated in detail. The overall means and standard deviations are $k=0.010 \mathrm{SI}(\mathrm{s} . \mathrm{d} .=0.003), J_{\mathrm{NRM}}=$ $1.7 \mathrm{~A} / \mathrm{m}$ (s.d. $=1.3$ ) and $Q=2.8$ (s.d. $=3$ ), respectively. The susceptibility appears to be normally distributed in contrast to the NRM intensity values and the $Q$ ratio, which tend to be log-normal distributed. Tests in the field revealed only reversed polarities.

Acknowledgements. Support during the field work by Margrethe and W. Stuart Watt, as well as geological information later provided by W.S. Watt are greatly appreciated. Field work was in part supported by a grant from the Danish Natural Science Research Council to N.A.

\section{References}

Abrahamsen, N. \& Van der Voo, R. 1987: Magnetic susceptibility and palaeomagnetic collection of rocks from central and western North Greenland. Rapp. Gronlands geol. Unders 133, $133-139$.

Abrahamsen, N., Schönharting, G. \& Heinesen, M. 1984. Palaeomagnetism of the Vestmanna core and magnetic age and evolution of the Faeroe Islands, 93-108. In Berthelsen, O., Noe-Nygaard, A. \& Rasmussen, J. (ed.) The deep drilling project $1980-81$ in the Faeroe Islands. Annales Societatis Scientiarum Faeroensis, Suppl. 9, 158 pp.

Deer, W. A. 1976: Tertiary igneous rocks between Scoresby Sund and Kap Gustav Holm, East Greenland. In Escher, A. \& Watt, W. S. (ed.) Geology of Greenland, 404-429. Copenhagen: Geological Survey of Greenland.

Harland, W. B., Armstrong, R. L., Cox, A. V., Craig, L. E., Smith, A. G. \& Smith, D. G. 1990: A geological time scale 1989, 263 pp. Cambridge University Press.

Henkel, H. 1991: Petrophysical properties (density and magnetization) of rocks from the northern part of the Baltic Shield. Tectonophysics 192, 1-19.
Kristiansson, L. \& Deutsch, E. R. 1973: Magnetic properties of rock samples from the Baffin Bay coast. In Hood, P. J. (ed.) Earth science symposium on offshore Eastern Canada. Geol. Surv. Can. Paper 71-23, 573-598.

Larsen, L. M. Watt, W. S. \& Watt, M. 1989: Geology and petrology of the Lower Tertiary plateau basalts of the Scoresby Sund region, East Greenland. Bull. Gronlands geol. Unders. 157, 164 pp.

Noe-Nygaard, A. 1976: Tertiary igneous rocks between Shannon and Scoresby Sund, East Greenland. In Escher, A. \& Watt, W. S. (ed.) Geology of Greenland, 386-402. Copenhagen: Geological Survey of Greenland.

Nordgerd, P. 1991: Magnetiske undersøgelser af plateau basalter i nordlige Østgrønland. M.Sc. Thesis, Aarhus University, 98 pp.

Sharma, P. V. 1976: Magnetic properties of some Tertiary basalts from West Greenland. Pure Appl. Geophys. 114, 195206.

Tarling, D. H. 1970: Palaeomagnetic results from the Faeroes Islands. In Runcorn, S. K. (ed.) Palaeogeophysics, 193-208. London: Academic Press.

Tarling, D. H. \& Otulana, H. I. 1972: The palaeomagnetism of some Tertiary igneous rocks from Ubekendt Ejland, West Greenland. Bull. geol. Soc. Denmark 21, 395-406.

Tarling, D. H., Hailwood, E. A. \& Løvlie, R. 1988: A palaeomagnetic study of lower Tertiary lavas in E Greenland and comparison with other lower Tertiary observations in the northern Atlantic. In Morton, A. C. \& Parson, L. M. (ed.) Early Tertiary volcanism and the opening of the NE Atlantic. Spec. Publ. geol. Soc. Lond. 39, 215-224.

Upton, B. G. J., Emeleus, C. H. \& Hald, N. 1980: Tertiary volcanism in northern E. Greenland: Gauss Halvø and Hold with Hope. J. geol. Soc. Lond. 137, 491-508.

Waagstein, R. 1988: Structure, composition and age of the Faeroe basalt plateau. In Morton, A. C. \& Parson, L. M. (ed.) Early Tertiary volcanism and the opening of the NE Atlantic. Spec. Publ. geol. Soc. Lond. 39, 225-238.

Watt, W. S. 1994: Stratigraphy and correlation of the Tertiary plateau basalts in North-East Greenland. Rapp. Gronlands geol. Unders. 162 (this volume). 